\title{
Factors influencing growth of giant terrestrial robber crab Birgus latro (Anomura: Coenobitidae) on Christmas Island
}

\author{
Michelle M. Drew ${ }^{1, *}$, Michael J. Smith ${ }^{2}$, Bill S. Hansson ${ }^{1}$ \\ ${ }^{1}$ Max Planck Institute for Chemical Ecology, Hans Knoell Strasse 8, 07745 Jena, Germany \\ ${ }^{2}$ 1/10 Leonora St, Como, Western Australia 6798, Australia
}

\begin{abstract}
Birgus latro has significant conservation and socio-economic importance throughout its range, yet very little is known about its growth in its natural habitat. An extensive markrecapture program was undertaken on Christmas Island, Australia, in which over 1440 individual crabs were uniquely identified using passive integrated transponder (PIT) tags. Over $18 \%$ of the tagged population was recaptured at least once and remeasured, providing substantial information on growth of $B$. latro. Our results show that in its natural setting $B$. latro is a very slow-growing species. Individuals commonly experience conditions that result in zero or negative growth. Sex, size, and injury all strongly influence the crab's moult increment. Males approached zero growth at around $65 \mathrm{~mm}$ in thoracic length (TL), while growth in females started to plateau at around $50 \mathrm{~mm}$ TL. Injury frequently led to negative growth, particularly in individuals that had lost a claw and/or multiple limbs - presumably due to a loss of foraging opportunities or access to other resources and a redistribution of available energy into limb regrowth. Our study indicates that previous growth curves do not adequately describe the growth of $B$. latro in its natural setting and that individual crabs may live over 30 yr longer than previously predicted, with large crabs likely to be over 100 years old. This may have serious implications for the long-term conservation of the species in the face of continuing exploitation.
\end{abstract}

KEY WORDS: Birgus latro $\cdot$ Growth $\cdot$ Moult increment $\cdot$ Mark-recapture $\cdot$ PIT tag $\cdot$ Conservation Resale or republication not permitted without written consent of the publisher

\section{INTRODUCTION}

Birgus latro (L.) or the robber crab is the largest terrestrial arthropod in the world (Lavery et al. 1996). This hermit crab is widely distributed on remote tropical islands of the Indo-Pacific, but populations are rapidly declining (Brown \& Fielder 1991, Schiller 1992, Lavery et al. 1996). It has been listed as 'Vulnerable' on the IUCN Red List since 1981 but was downgraded to 'Data deficient' in 1996 (Eldredge 1996). The robber crab has significant socio-economic value throughout most of its range-it is offered as a speciality dish in tourist restaurants in the Pacific (Environment Unit 2006) including Japan (Sato \& Yoseda 2010), yet there is a lack of accurate growth data, which limits the development of adequate management protocols (Fletcher et al. 1990a, Sato \& Yoseda 2008, Buden 2012).

Traditional methods of aging finfish using structures such as otoliths, spines and vertebrae cannot be used on crustaceans as the loss of the exoskeleton during moulting eliminates the availability of hard structures typically used for aging and assessing growth over time (Chang et al. 2011). More recently, Kilada et al. (2012) identified that some crustaceans retain hard parts in the eye stalk and gastric mill through a moult and suggest that counts of the growth bands formed on the calcified parts can be used to accurately age some crustacean species. However, the accuracy and value of this method has yet to be shown in all crustaceans. Several authors (Held 1963, Reese \& Kinzie 1968, Amesbury 1980, Fletcher et al. 1990a, 1991, 
Robertson 1991) have attempted to maintain Birgus latro in captivity in order to monitor moult increment and moult frequency in a controlled environment. However, most studies on crabs $>30 \mathrm{~mm}$ thoracic length (TL) were deemed unsuccessful as crabs either did not moult before dying in captivity or the majority of moulted individuals had negative or zero growth. Smaller crabs held in captivity grew well, providing some good early growth information, but most studies terminated the experiments after 2.5 yr (Held 1963, Reese \& Kinzie 1968), well before the crabs reached sexual maturity; believed to be at around 24.5 to $32 \mathrm{~mm}$ TL in females (Sato \& Yoseda 2008), $22.2 \mathrm{~mm}$ TL in males (Sato et al. 2008) and at ca. 5 to $10 \mathrm{yr}$ of age, as determined by the growth curve provided by Fletcher et al. (1990a).

A number of mark-recapture studies have been undertaken on Birgus latro in an attempt to improve knowledge of their growth in a natural setting, but with limited success (see Drew et al. 2010 for a review). One of the primary problems with markrecapture programs has been the inability of the mark to be retained through ecdysis (Drew et al. 2012); external tags are lost during the moult process. Fletcher et al. (1989) attempted to alleviate the problem of retaining marks post-moult by using heat and freeze branding methods, enabling them to identify individual crabs for up to 3 yr. However, only a small number of crabs were recaptured, providing growth information for less than 30 individuals (Fletcher et al. 1990a). Long-term growth was subsequently estimated using the data from the recaptured individuals in addition to measurements taken from unmarked crabs that had been excavated from their moult burrows in the field, and from a few individuals that had moulted in captivity and which had recorded positive growth. Fletcher et al. (1990a) acknowledged that growth models derived from the small number of crabs from a limited size class (40 to $77 \mathrm{~mm} \mathrm{TL}$ ) were unlikely to be very robust.

Growth of decapod crustaceans is known to be affected by a variety of biotic and abiotic factors. Research has shown that sex (Sheehy et al. 1999, Hartnoll 2006), size (Fletcher et al. 1990a), injury (Hopkins 1982, Norman \& Jones 1991, Juanes \& Smith 1995), resources (see Hartnoll 2001 for a review), environmental conditions (Cockcroft \& Goosen 1995, Hartnoll 2001) and, for terrestrial decapods, access to suitable moulting locations (Bliss \& Boyer 1964), are all likely to influence growth and potentially the intermoult duration. Birgus latro is a sexually dimorphic species, with males attaining a much greater size than females throughout its range (Drew et al.
2010). The species is also known to engage in aggressive behaviour (Gibson-Hill 1947, Helfman 1977) and Fletcher et al. (1990a) observed that moult increment (MI) in B. latro was on average smaller in large individuals compared to small crabs.

Drew et al. (2012) recently conducted field experiments on Birgus latro using internal microchips or passive integrated transponder (PIT) tags on Christmas Island, Australia. The tags were retained well through several moults, enabling the growth of individuals to be monitored over several years. In addition, initial recapture rates were substantially higher than in previous studies (ca. $15 \%$ on Christmas Island in Drew et al. 2012, compared to $<1 \%$ on Santo Island, Vanuatu; Fletcher et al. 1990b). We examined the moult increment data collected from individuals tagged as part of Drew et al. (2012), and since Drew et al. (2012) routinely monitored size, sex and injuries on tagged crabs in their study, we used this data to attempt to determine what impact these factors may have on the MI of B. latro.

\section{MATERIALS AND METHODS}

\section{Study site}

Christmas Island, Australia, is a relatively large $\left(135 \mathrm{~km}^{2}\right)$ oceanic island ca. $360 \mathrm{~km}$ south of Java, in the Indian Ocean (Fig. 1). Approximately $60 \%$ of the island is national park and the island has one of the largest populations of Birgus latro in the world. Since the passing of legislation in 1978, crabs within the National Park and on the golf course have been fully protected, while crabs occurring outside these areas may only be taken in small quantities by locals for private on-island consumption. No commercial exploitation is permitted (Drew et al. 2012).

\section{Mark-recapture}

A total of 1441 crabs (744 females) were injected with ENSID (ENSID Technologies; www.ensid.com) food safe RFID $11 \mathrm{~mm}$ FDX PIT tags using a singleshot Simcro stainless steel implanter. Crabs were injected on the right hand side of the abdomen just below the second tergum plate (Fig. 2a, see Drew et al. 2012 for more details). Tags were scanned immediately after injection using a FDX reader (see Drew et al. 2012 for further details) and the number recorded. The dorsal surface of the cephalothorax of the tagged crab was photographed (e.g. Fig. 2b), and the TL 


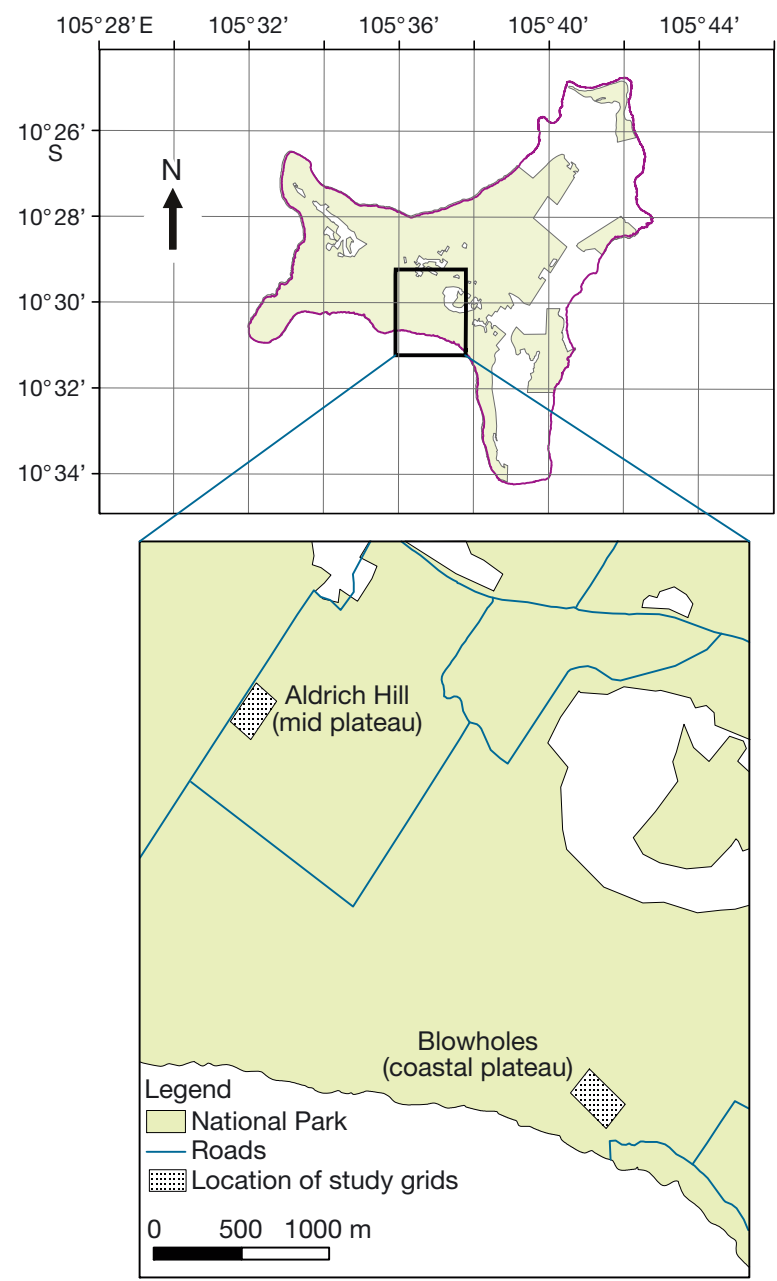

Fig. 1. Location of study sites on Christmas Island, Australia

measured (see Fig. 2a) to the nearest $0.1 \mathrm{~mm}$ using vernier callipers. To ensure accuracy and to understand the potential for error, the TL of every 5 th crab tagged or recaptured was measured 3 times by the same observer. Error values in the TL measurements were then calculated from this data. Tagged crabs were also weighed, sexed (identified by the presence or absence of pleopods on the left ventral side), injuries noted and photographed for comparison with any recaptures, externally marked on the head and right hand side of the carapace with paint (as per Drew et al. 2012), and released at the capture site.

Injuries were defined as: damage to any part of the crab, including punctures, crushed body parts and/or loss of a limb or part thereof. All tagged and recaptured individuals were assessed for injury. Injured body part(s), type of injury (limb loss, puncture wound, crush, etc) and any indication of regeneration were noted and photographed. Older injuries were identified by the level of regeneration. Partial regeneration of the cephalothorax associated with puncture wounds were identified by some regrowth of the shell but not complete closure of the wound. Scarring was often evident on the cephalothorax in the form of old puncture wounds and these were noted as such. Regenerating limbs were observed to take at least 2 moults before they attained their preloss size and injured parts often exhibited a significantly different colour to limbs that had not recently been subjected to loss (e.g. Fig. 2f). Partial regeneration of the limbs was identified by any variation in the colour or size of the limb compared to the corresponding limb on the other side. Limbs not yet at full size or a different colour were noted and photographed to enable later comparison with existing or future photos. Deformity was defined as: a major variation in the shape of a body part compared to the average shape of that part (e.g. Fig. 2e). Deformities were noted including body part and their main characteristics, and photographed.

Crabs were tagged at 2 unbaited sites within the Christmas Island National Park (see Fig. 1). Between May 2009 and December 2010 crabs were tagged in three 1 ha grids (shown as a single area on the map), located on the mid-plateau (Aldrich Hill) and between September and December 2010, crabs were tagged in a further three 1 ha grids located on the coastal plateau (Blowholes, Fig. 1). The grids were thoroughly searched in daylight hours each month and all specimens $>30 \mathrm{~mm}$ TL and $250 \mathrm{~g}$ wet wt were captured by hand and tagged or in the case of recaptures, remeasured. Crabs $<30 \mathrm{~mm}$ TL or $250 \mathrm{~g}$ wet wt were not tagged but were captured, weighed, measured and externally marked with paint before release (see Drew et al. 2012 for justification of minimum size for tagging).

After December 2010, grids were visited weekly until October 2011 and then monthly to June 2012, to locate previously tagged crabs. In addition, opportunistic scanning of crabs was conducted when other field work (e.g. radio tracking) was being conducted within the vicinity (ca. $2 \mathrm{~km}$ ) of the tag sites. All recaptures were noted, assessed for injuries, re-measured and re-photographed, with additional photographs taken if injuries or regeneration of limbs or cephalothorax were noted.

\section{Moult assessment}

Evidence of a moult between captures was clear in some individuals due to the regrowth of a limb or cephalothorax following an injury, or a significant 


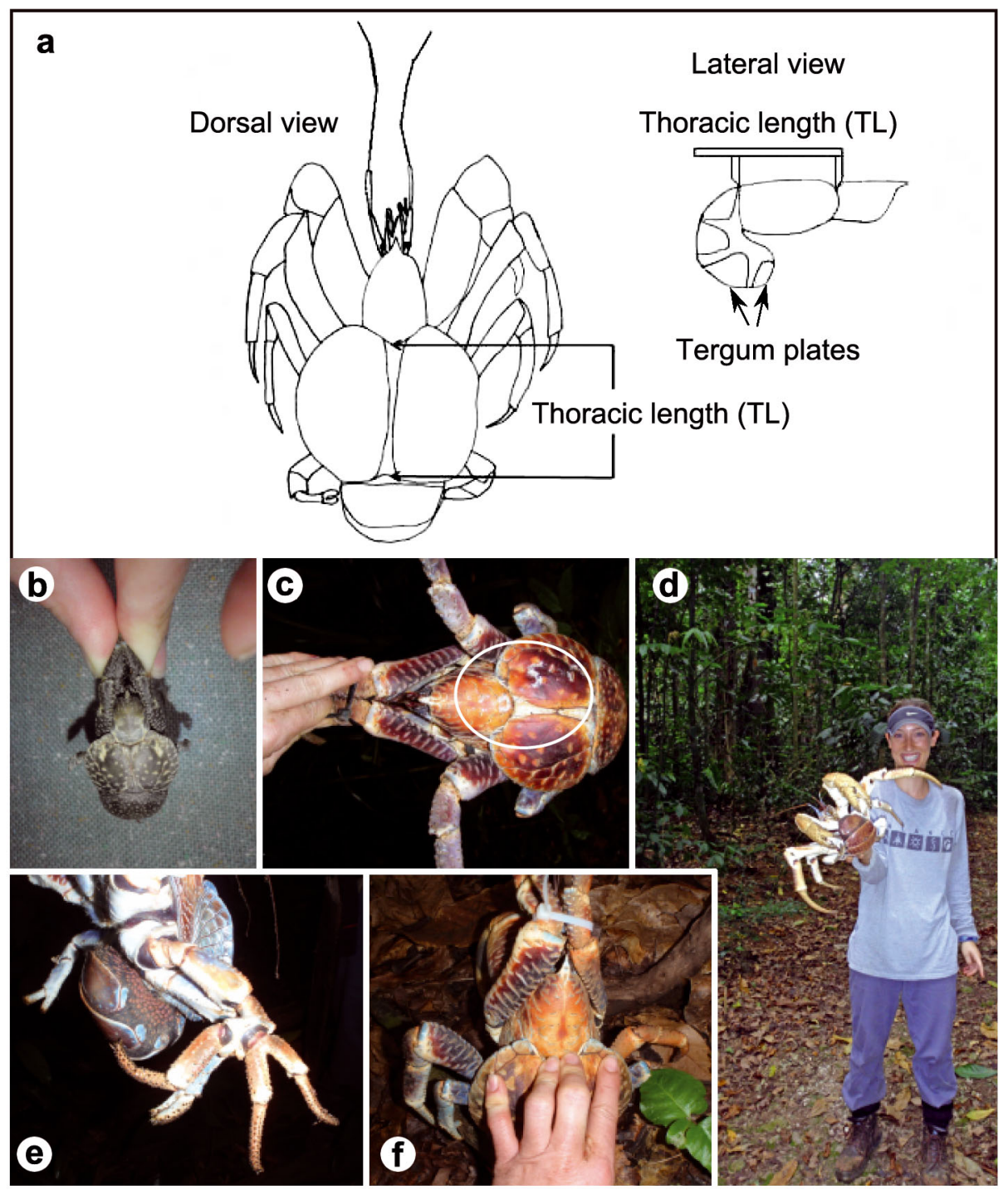

Fig. 2. Birgus latro. (a) Thoracic length (TL) measurement from dorsal and lateral views (modified from Fletcher \& Amos 1994, and Drew et al. 2010). (b) Male B. latro ca. $12 \mathrm{~mm}$ TL, showing the dorsal view photographed for each individual tagged. (c) Female $45.5 \mathrm{~mm}$ TL, showing traces of white paint on the right side of the carapace and head, $273 \mathrm{~d}$ after tagging. (d) Male $>70 \mathrm{~mm}$ TL. (e) Male crab with a deformity of the second walking leg. (f) First and second walking legs on the right side of this individual are smaller and have a different colour compared to the same legs on the left side indicating regeneration of the limbs

change in size. However, it was not always possible to determine if a moult had occurred between captures in an uninjured individual or to determine how many moults may have occurred in this period. This was particularly difficult if a crab recorded a negative or zero growth and more so in the second year of data collection when many individuals had not been seen for 2 or 3 years and may have moulted multiple times. Fletcher et al. (1991) identified that Birgus latro on Vanuatu moulted once per year during winter months. In order to standardise the data for the generalised linear regression model, it was assumed that crabs on Christmas Island also moulted annually in the period between April and August (the period of highest density of crab burrows in the area) and crabs recaptured after this period were assumed to have moulted, unless evidence suggested otherwise (e.g. presence of external marks, no limb regrowth). Crabs recaptured within a moult period were assumed not to have moulted unless a full moult period had passed between captures or unless photographic evidence suggested a moult. Crabs recaptured over 2 full moult periods were assumed to have moulted 2 times between captures. 


\section{Data analyses}

All crabs tagged and remeasured between May 2009 and June 2012 were included in the analyses $(\mathrm{N}=$ 272). In the instance where a crab was recaptured multiple times in this period only the initial and final recapture data were included in data analyses. Graphical examination of the data clearly indicated that a linear modelling approach was appropriate. Consequently, we used a generalised linear regression model (GLM) within a Bayesian framework (Kéry 2010) with MI (i.e. the proportion change in TL relative to the TL at tagging), as the dependent variable and sex (male $=1$ and female $=0$ ), TL (at tagging), moult periods (MP; the number of full moult periods between tagging and recapture: 0,1 , or 2 ) and injury (recorded at tagging or injury with some regeneration at recapture $=1$ and no injury $=0$ ) as the independent predictor variables (Model 1). The model also incorporated 4 interactive terms that were believed to be important a priori. Moult increment was modelled as normal with prior precision given a gamma $(0.001,0.001)$ distribution (Kéry 2010, Kerman 2011).

Model 1:

Moult Increment $=$ Intercept $+\beta_{1} \cdot \operatorname{Sex}+\beta_{2}$.

Injury $+\beta_{3} \cdot \mathrm{TL}+\beta_{4} \cdot \mathrm{MP}+\beta_{5} \cdot \operatorname{Sex} \cdot \mathrm{TL}+\beta_{6} \cdot$

Injury $\cdot \operatorname{Sex}+\beta_{7} \cdot \operatorname{Injury} \cdot \mathrm{TL}+\beta_{8} \cdot \mathrm{MP} \cdot \operatorname{Sex}$

All values of the dependent variable were standardised by subtracting the mean and dividing by the standard deviation. The model was fitted to the data using OpenBUGS v.1.4 (Lunn et al. 2009) that was initiated through $\mathrm{R}$ software (R Development Core Team 2007) using the R2WinBUGS package (Sturtz et al. 2005). Three replicate Markov chains were run with different starting values for 150000 iterations with every 50th iteration kept and the first 10000 iterations were discarded. Convergence of the algorithm was assessed with the Brooks-GelmanRubin convergence statistic (Brooks \& Gelman 1998) and the R-hat statistic (R-hat values between 1.0 and 1.1 indicate acceptable convergence; Kéry 2010). The model intercept and $\beta$ estimates were given uninformative or vague normal $\left(0,1.0 \leftrightarrow 10^{-6}\right)$ priors. We assessed model sensitivity to these priors by comparing the estimates of the initial model with those in models that used uniform $(-20,20)$ priors (Kéry 2010). Credibility intervals (CRI) are calculated for alpha and each $\beta$ estimate (mean) providing the probability that the $\beta$ estimate lies within the calculated interval (Royle \& Dorazio 2008). Credibility intervals that include zero are considered to be statistically unsupported by the model (Kéry 2010).

\section{Growth curves}

In order to estimate the relative age-at-size for males and females, the annual change in TL was estimated for each recaptured crab based on the following formula:

Annual change in TL $=$

$\Delta$ TL between tagging \& recapture as a $\%$ of TL at tagging $\times 365 \mathrm{~d}$ number of days at liberty

Using the estimates from Eq. (2), the annual change in TL was then averaged across $5 \mathrm{~mm}$ TL size classes, based on the TL at tagging for males and for females. The average annual change in TL calculated for each size class and sex was then used to estimate growth curves to maximum size recaptured $(73.8 \mathrm{~mm}$ in TL for males and $53.3 \mathrm{~mm}$ in TL for females) or size at which growth became negative for males and for females. The average annual increase in TL for the first size category recaptured was added to the smallest TL within the first size category and then again to the resulting TL iteratively, until the TL reached the next size class, at which point the average value calculated from Eq. (2) appropriate to that size class was added to the TL and so on, to generate growth curves for males and for females.

Size classes for the calculation of the growth curves commenced according to the smallest recaptured individuals, which was $40.0 \mathrm{~mm}$ TL for males and $35.3 \mathrm{~mm}$ TL for females. Growth curves are therefore based on the number of years for a crab to reach maximum size from the above minimum size classes and do not represent the absolute age.

Unlike the GLM model, this growth curve makes no assumption with regard to moulting. Eq (2) calculates a change in thoracic length on an annual basis (365 d) using the change in the TL of the individual between tagging and final recapture and the time it was at liberty. Average growth is then calculated for each $5 \mathrm{~mm}$ TL size class to give an average change in TL per year. This alleviates the problem of assuming all crabs moult annually (for which there is limited supporting data, e.g. Hartnoll 1982, Stewart \& Kennelly 2000) and will provide a very conservative estimate of average growth for the population regardless of moulting frequency for an individual.

Fletcher et al. (1991) identified that small individuals were able to complete moulting in $<1$ mo whilst larger individuals were noted to take up to 3 mo. In order to minimise bias to the data as a result of measurement error, all crabs at liberty <90 d were assumed to have zero growth (15 males and 9 females). In addition, any crabs clearly known not to have moulted (i.e. paint on shell at recapture) with a 
change in TL were assumed to have zero growth for the model, as it was assumed the change in TL was a result of measurement error (6 males and 9 females).

\section{RESULTS}

A total of 328 individual crabs were resighted 440 times to June 2012, giving a resight rate of $22.5 \%$ of the tagged population. A total of 272 crabs were recaptured at least once and re-measured (Table 1). Of these, 209 (99 males) were recaptured after at least one full moult period (Table 1; see 'Materials and methods' for assumptions). There was a distinct lack of small $(<30 \mathrm{~mm}$ TL) individuals captured throughout the study, and as no tags were placed in individuals with $<30 \mathrm{~mm} \mathrm{TL}$, no growth data is available for this group of crabs. In addition, there were relatively few (ca. 100) male crabs with $<40 \mathrm{~mm}$ TL captured and tagged, compared to nearly 300 females in this size category. Of the 100 males $<40 \mathrm{~mm}$ TL tagged, none were physically recaptured by June 2012, compared to ca. $11 \%$ of the tagged females in this size category (Table 2).

Table 1. Birgus latro. Total number of crabs recaptured after each full moult period and the injury rate in each category. 'Other injury' refers to any injury or deformity to the cephalothorax, or abdomen or a localised break in exoskeleton, but no loss of limb. Values in parentheses are the number of crabs excluded from the model because the injury occurred after the last moult period

\begin{tabular}{|c|c|c|c|c|c|c|c|c|}
\hline \multirow[b]{2}{*}{ No. full moults periods between captures } & \multicolumn{4}{|c|}{ Males } & \multicolumn{4}{|c|}{ Females } \\
\hline & 0 & 1 & 2 & Total & 0 & 1 & 2 & Total \\
\hline Total no. crabs recaptured & 33 & 79 & 20 & 132 & 30 & 77 & 33 & 140 \\
\hline Total no. injured crabs recaptured & 8 & $17(1)$ & $5(1)$ & $30(2)$ & $\mathbf{0}$ & $6(1)$ & 6 & $12(1)$ \\
\hline Injury type: Loss of chelae/multiple limbs & 3 & 8 & 1 & 12 & 0 & 1 & 0 & 1 \\
\hline Loss of single limb & 1 & $4(1)$ & 1 & $6(1)$ & 0 & 3 & 2 & 5 \\
\hline Other injury & 4 & 5 & $3(1)$ & $12(1)$ & 0 & $2(1)$ & 4 & $6(1)$ \\
\hline
\end{tabular}

Table 2. Birgus latro. Summary of all crabs tagged and recaptured, including injury data. Injury at tagging: crabs that had an injury, deformity or had a regenerating injury at tagging; at recapture: injury recorded at recapture but there was some regeneration (indicating that a moult had occurred after the crab received the injury); post: crab had been at liberty over one or more full moult periods which recorded an injury at recapture but there was no regeneration, indicating that the injury had been sustained after the most recent moult

\begin{tabular}{|c|c|c|c|c|c|c|}
\hline \multirow[t]{2}{*}{$\begin{array}{l}\text { Size category } \\
\text { TL }(\mathrm{mm})\end{array}$} & \multicolumn{2}{|c|}{ No. of crabs } & \multirow[t]{2}{*}{$\begin{array}{l}\text { Days at liberty } \\
(\text { mean } \pm \text { SE) }\end{array}$} & \multicolumn{3}{|c|}{$\begin{array}{l}\text { No. of recaptured crabs with an injury, } \\
\text { regeneration or deformity }\end{array}$} \\
\hline & & & & At tagging & At recapture & Post \\
\hline \multicolumn{7}{|l|}{ Females } \\
\hline$<34.9$ & 77 & 1 & 0 & 0 & 0 & 0 \\
\hline $35-39.9$ & 201 & 25 & $396 \pm 51.7$ & 1 & 0 & 0 \\
\hline $40-44.9$ & 293 & 68 & $472 \pm 31.2$ & 5 & 2 & 1 \\
\hline $45-49.9$ & 147 & 39 & $393 \pm 26.2$ & 2 & 1 & 0 \\
\hline $50-54.9$ & 24 & 7 & $389 \pm 53.2$ & 1 & 0 & 0 \\
\hline $55-59.9$ & 2 & 0 & 0 & 0 & 0 & 0 \\
\hline Total & 744 & 140 & - & 9 & 3 & 1 \\
\hline \multicolumn{7}{|l|}{ Males } \\
\hline$<34.9$ & 48 & 0 & 0 & 0 & 0 & 0 \\
\hline $35-39.9$ & 64 & 0 & 0 & 0 & 0 & 0 \\
\hline $40-44.9$ & 64 & 10 & $502 \pm 62.1$ & 1 & 1 & 0 \\
\hline $45-49.9$ & 82 & 9 & $377 \pm 98.5$ & 0 & 0 & 0 \\
\hline $50-54.9$ & 102 & 23 & $396 \pm 44.2$ & 5 & 2 & 1 \\
\hline $55-59.9$ & 100 & 22 & $366 \pm 57.7$ & 3 & 1 & 0 \\
\hline $60-64.9$ & 120 & 38 & $435 \pm 37.2$ & 9 & 2 & 1 \\
\hline $65-69.9$ & 87 & 25 & $391 \pm 42.2$ & 3 & 2 & 0 \\
\hline $70-74.9$ & 28 & 5 & $406 \pm 104.2$ & 1 & 0 & 0 \\
\hline $75-79.9$ & 2 & 0 & 0 & 0 & 0 & 0 \\
\hline Total & 697 & 132 & - & 22 & 8 & 2 \\
\hline
\end{tabular}


A total of 45 of the recaptured crabs (32 male: Table 1) had suffered an injury. Of these, 3 crabs (2 male and 1 female) had moulted between captures but they had received the injury after the most recent moult preceding the recapture (i.e. the injury could not have influenced the change in TL at the most recent moult) and these individuals were marked as 'uninjured' for the model (i.e. 42 crabs - 30 male and 12 female-were included as injured in the model). Males were more likely to have experienced injuries to the cheliped or to have multiple injuries $-40 \%$ of injured males that were recaptured had sustained this type of injury compared to only $8 \%$ of injured females recaptured (Table 1). Crabs with multiple injuries or injuries to the cheliped recorded on average a more substantial decrease in TL compared to other injury types (Table 3).

\section{GLM model: Moult increments}

The Bayesian p-value for the model was 0.489, indicating a good model fit. Values around 0.5 show a good model fit while values close to zero or one indicate a poor model fit (Kéry 2010). The model indicated that growth in Birgus latro was strongly influenced by sex, TL, injury and the number of full moult periods that had passed between tagging and recapture (Table 4). As expected, sex had a strong positive influence on the model with males averaging much larger MI compared to females (Table 4 and Fig. 3).

MI were negatively correlated with size (TL) of the crab at tagging, indicating that as crabs got larger, moult increments on average decreased (Fig. 3). As predicted by the model, moult increments approached zero in females once individuals had reached $50.4 \mathrm{~mm}$ TL (CRI: $-0.81,0.86)$ and zero in males at $65.3 \mathrm{~mm}$ TL (CRI: -0.52, 0.52) (Fig. 3). There was a positive relationship between the number of full moult periods between tagging and recapture and $\mathrm{MI}$ — crabs had larger MI the longer they were at liberty (Fig. 4). The interaction between moult periods and sex was not statistically supported by the model, as the CRI included zero (Kéry 2010) suggesting that declines in MI over time (moult periods) are consistent between the sexes.

\section{Injury and MI}

As predicted by the model, injured crabs had a greater probability of experiencing zero or negative MI between tagging and final recapture compared to uninjured crabs (mean $=-0.640$, Table 4, Fig. 5). The
Table 3. Birgus latro. Summary of injury and moult increment, as a percentage of thoracic length ( $\mathrm{TL}, \mathrm{mm}$ ) at tagging (mean $\pm \mathrm{SE}$ ), for all crabs at liberty for at least one full moult after receiving the injury. Moult increment has been standardised by dividing the moult increment by the number of full moult periods that had passed while the crab was at liberty

\begin{tabular}{|lccr|}
\hline & $\begin{array}{c}\text { No. of } \\
\text { males }\end{array}$ & $\begin{array}{c}\text { No. of } \\
\text { females }\end{array}$ & $\begin{array}{c}\text { Moult incre- } \\
\text { ment (\%) }\end{array}$ \\
\hline Multiple limbs/chelae & 9 & 1 & $-1.65 \pm 0.59$ \\
Single limb (not chelae) & 4 & 5 & $-0.03 \pm 0.63$ \\
Other injury & 9 & 6 & $0.06 \pm 0.40$ \\
Total & 22 & 12 & $-0.57 \pm 0.30$ \\
\hline
\end{tabular}

Table 4. Birgus latro. Posterior parameter (intercept and slope) estimates from the generalised linear regression model (Model 1) including mean, standard deviation (SD), $2.5 \%$ and $97.5 \%$ credibility intervals (CRI) for each normalised independent predictor variable: TL (thoracic length at tagging, in $\mathrm{mm})$, Sex (male $=0$, female $=1$ ), moult period (number of moult periods between tagging and final capture) and injury (yes $=1$ or no $=0) . \mathrm{N}=272$ (140 females)

\begin{tabular}{|lrrrr|}
\hline Parameter & Mean & SD & $2.5 \%$ CRI & $97.5 \%$ CRI \\
\hline Intercept & 1.226 & 0.261 & 0.709 & 1.223 \\
Sex & 1.276 & 0.257 & 0.769 & 1.277 \\
Injury & -0.640 & 0.155 & -0.945 & -0.640 \\
TL & -1.148 & 0.286 & -1.703 & -1.148 \\
Moult periods & 0.592 & 0.141 & 0.316 & 0.592 \\
Sex $\times$ TL & -0.462 & 0.284 & -1.025 & -0.461 \\
Injury $\times$ Sex & -0.849 & 0.233 & -1.308 & -0.849 \\
Injury × TL & 0.830 & 0.221 & 0.393 & 0.831 \\
Moult periods $\times$ Sex & 0.054 & 0.140 & -0.219 & 0.055 \\
\hline
\end{tabular}

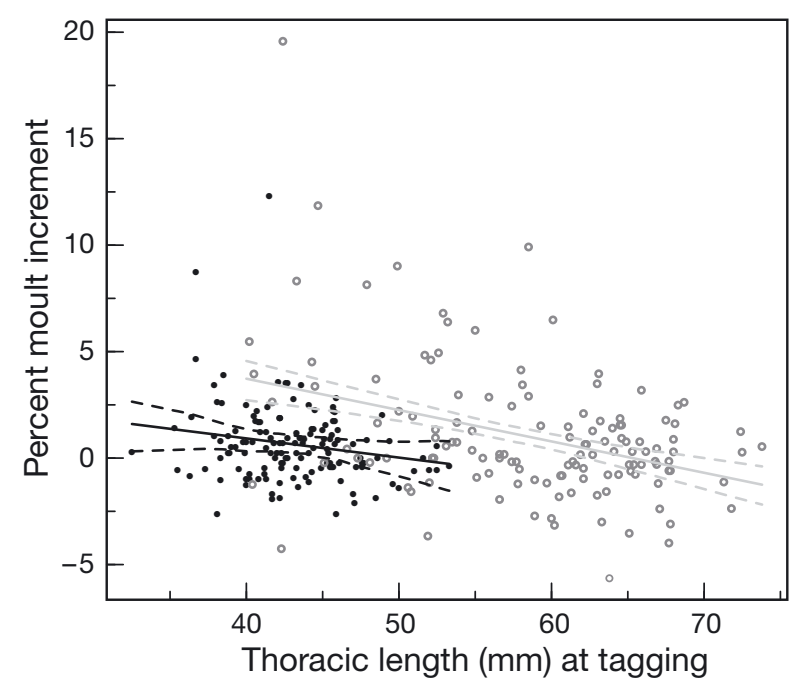

Fig. 3. Birgus latro. Percent moult increment (MI) relative to thoracic length (TL) at tagging for male $(0, n=132)$ and female $(\bullet, \mathrm{n}=140)$. Predicted relationship between MI and TL (at tagging) represented by the solid line (mean estimate) and dashed lines $95 \%$ predicted credibility intervals. Males (grey), Females (black). All other predictor variables held as average values for each sex 


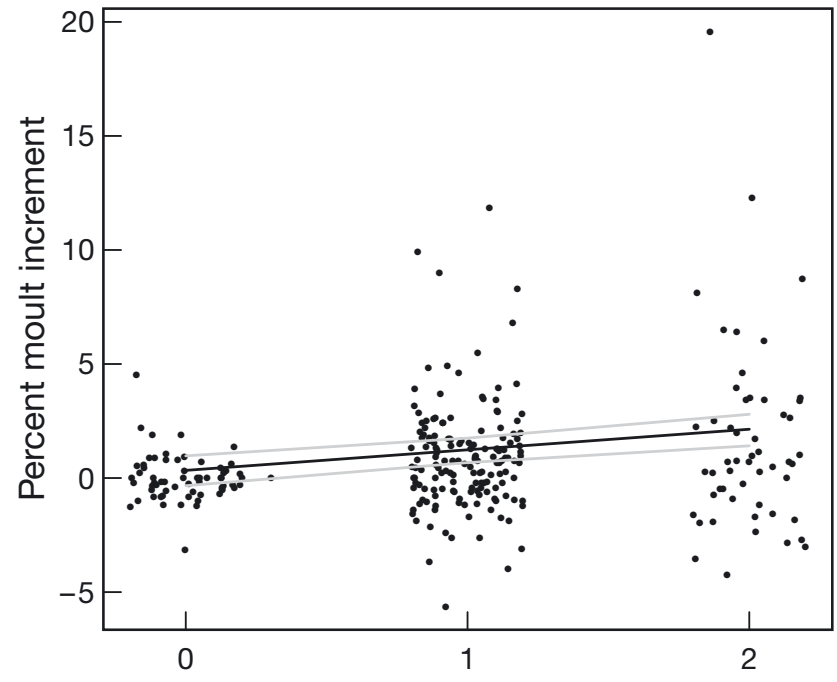

No. of full moult periods between captures

Fig. 4. Birgus latro. Percent moult increment relative to thoracic length (TL, $\mathrm{mm}$ ) at tagging in relation to the number of full moult periods that tagged crabs were at liberty. Data points have been jittered (Gelman \& Hill 2007) around the 3 full moult periods $(0,1$ and $2 ; \mathrm{n}=63,156$ and 53, respectively) to alleviate overplotting. The black line indicates the mean estimate and the grey lines $95 \%$ predicted credibility intervals. All other predictor variables were held as average values for the population

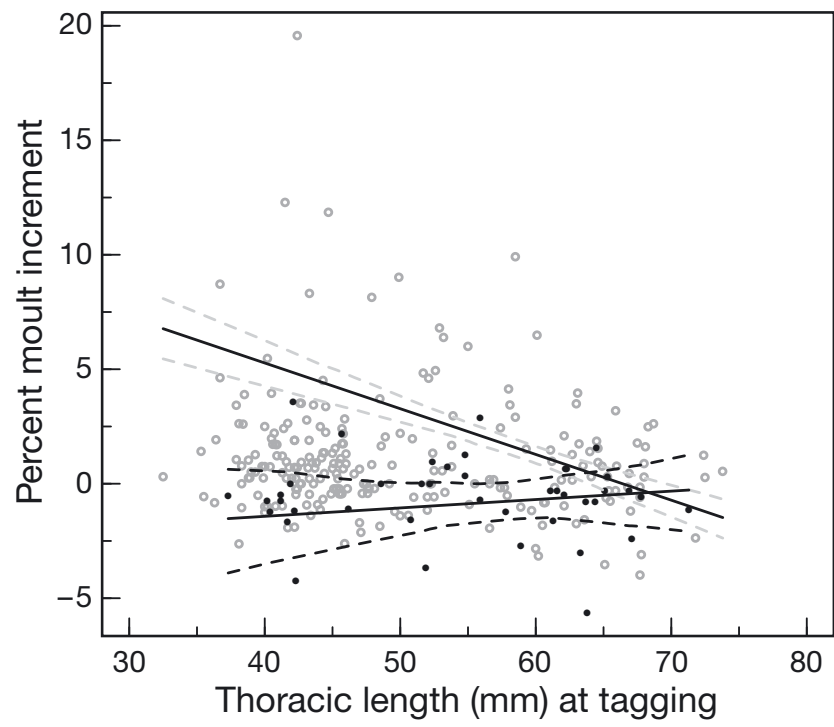

Fig. 5. Birgus latro. Percent moult increment relative to thoracic length (TL) at tagging in relation to injury. Injured $(\bullet$, $\mathrm{n}=42)$ and uninjured $(\circ, \mathrm{n}=230)$. Solid lines refer to the mean estimate and the dashed lines $95 \%$ predicted credibility intervals. Sex predictor variable set as male, with moult periods averaged for injured and uninjured respectively and TL predictor variables held as average values for the population positive interaction between injury and TL (mean = 0.830 , Table 4) shows that the impact of injury was more pronounced on small crabs than on large crabs (Fig. 5). Crabs approaching their maximum size were predicted to experience little growth regardless of injury status. Injured males were likely to experience much smaller MI (mean $\pm \mathrm{SE}=-0.789 \pm 0.32)$ compared to their uninjured counterparts $(1.553 \pm 0.34)$ and compared to both injured $(-0.05 \pm 0.43)$ and uninjured females $(0.72 \pm 0.19)$, with the model predicting a negative interaction between injury and sex (-0.849: Table 4, Fig. 6a,b).

\section{MI compared to other studies}

Fletcher et al. (1990a) discovered that a large proportion of individual Birgus latro held in captivity in their study had negative or zero growth. Believing that this was an artefact of captivity, individuals with negative or zero growth were excluded from further analyses. Following on from Fletcher et al. (1990a), and to provide appropriate comparison between studies, MI for different size classes for both male and female including negative and zero growth from this study were examined and compared to the MI for moulted individuals with positive growth only (Fig. 7). Over $36 \%$ of the crabs recaptured after a full moult period in our study displayed a zero or negative change in TL (Fig. 7). As shown in Fig. 7, the difference in average MI between all moulted crabs and moulted crabs with positive growth only increases in the larger size categories for both males and females.

\section{Growth}

Growth curves estimated from Eq. (2) show growth becoming negative at $49.9 \mathrm{~mm}$ TL in females and approaching zero at ca. $65.0 \mathrm{~mm}$ TL in males (Fig. 8). Estimates of time to grow to maximum captured size indicate that growth in Birgus latro is very slow, with females potentially taking $>70$ yr to grow from the minimum captured size of $35.3 \mathrm{~mm}$ up to $49.9 \mathrm{~mm}$ $\mathrm{TL}$, and males taking $>100 \mathrm{yr}$ to grow from $40 \mathrm{~mm}$ up to $65 \mathrm{~mm}$ TL. Using previous growth curves calculated by Fletcher et al. (1990a) to estimate the age of individual females at $35.3 \mathrm{~mm}$ TL and males at $40 \mathrm{~mm}$ TL (i.e. the minimum size recaptured in this study) and using this to calculate total age based on Eq. (2), B. latro males of $65 \mathrm{~mm}$ TL are likely to be $>120 \mathrm{yr}$ old and females of $49.9 \mathrm{~mm}$ TL are likely to be $>80$ yr old. 


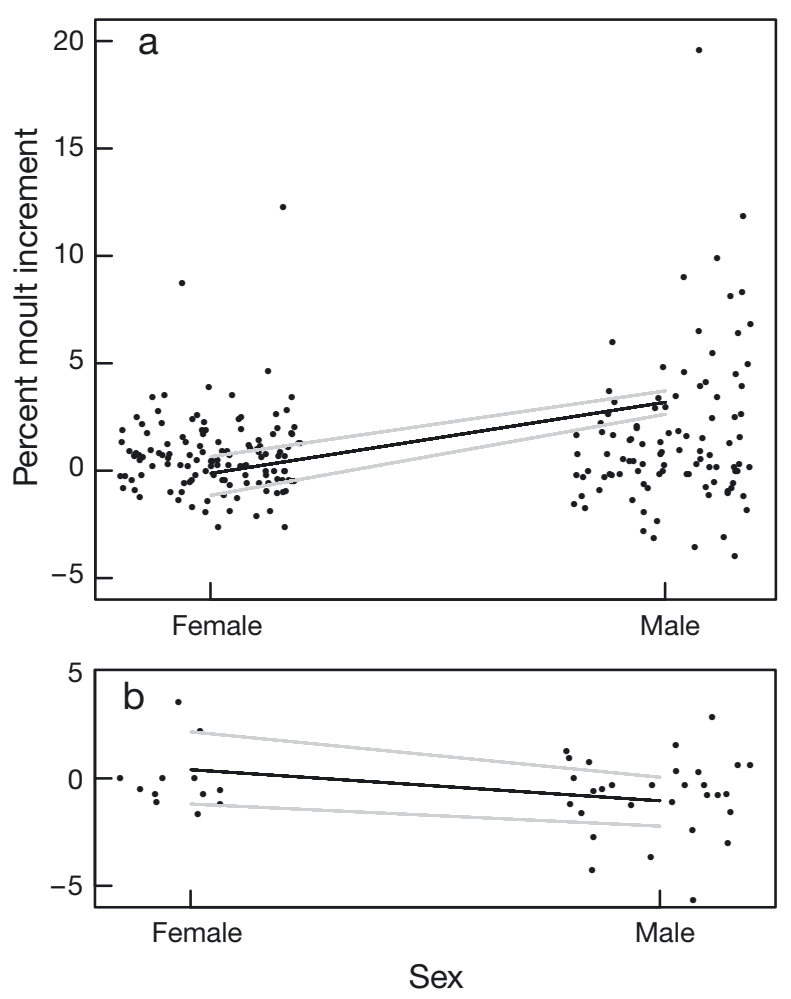

Fig. 6. Birgus latro. Percent moult increment relative to thoracic length (TL, $\mathrm{mm}$ ) at tagging in relation to sex for (a) uninjured $(\mathrm{n}=230)$ and $(\mathrm{b})$ injured $(\mathrm{n}=42)$ crabs. The solid line indicates mean the estimate and the grey lines $95 \%$ predicted credibility intervals. All other predictor variables were held as average values for the population. Data points have been jittered (Gelman \& Hill 2007) to alleviate overplotting and enable easier interpretation

\section{DISCUSSION}

In a major tagging effort, over 1440 B. latro were tagged using PIT tags on Christmas Island, Australia. Over $18 \%$ of the tagged crabs were recaptured at least once, doubling previous recapture rates of this species on this island. Of the 1700 females Schiller (1993) tagged in the National Park on Christmas Island using external carapace marks, only 150 or ca. $9 \%$ were recaptured. Relatively high recapture rates in our study, compared to Schiller (1993) may be attributable to the permanency of the PIT tags, which enabled longer monitoring of individuals (Drew et al. 2012).

Interestingly, males $<40 \mathrm{~mm}$ TL were captured infrequently compared to females of the same size class and none of the males $<40 \mathrm{~mm}$ TL that were tagged were recaptured ( 3 were scanned to identify them but due to their position in crevices we were unable to access them to remeasure or assess their moult condition). This may indicate that males in the
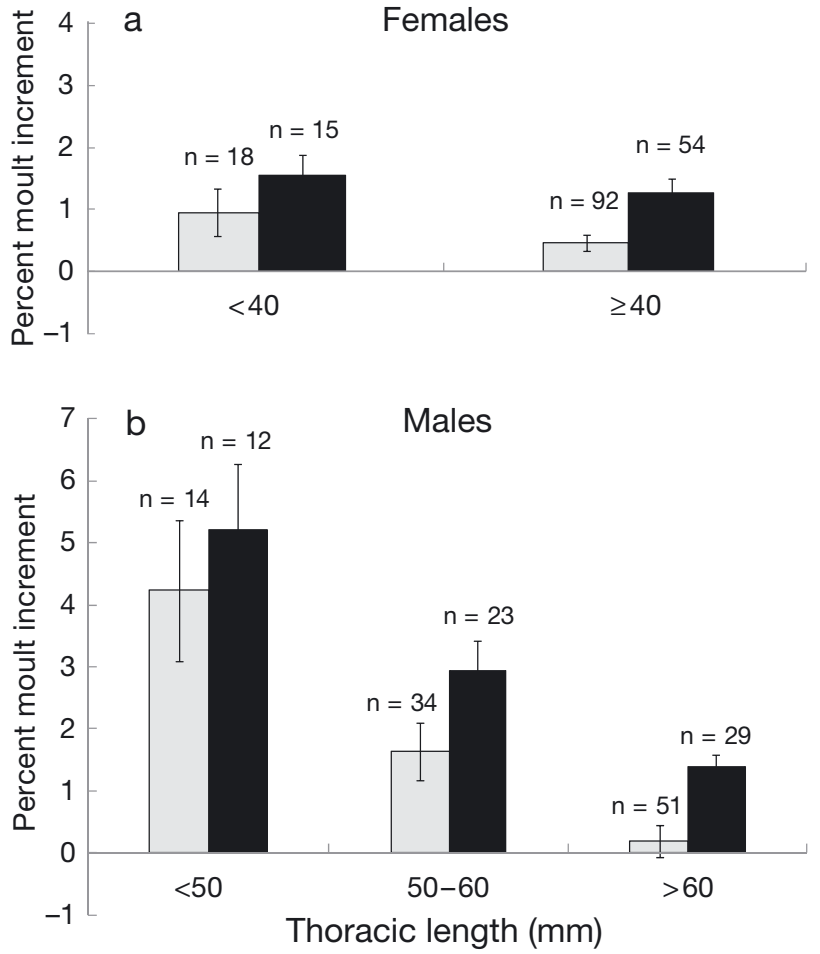

Fig. 7. Birgus latro. Percent moult increment (MI) of (a) females and (b) males recaptured after at least one full moult period with (grey bars) or without (black bars) individuals having zero or negative growth. $\mathrm{n}=$ number individuals included in each group. For individuals at liberty over multiple full moult periods, the MI was adjusted by dividing the change in thoracic length between tagging and recapture by the number of full moult periods that had passed between tagging and final recapture. Error bars $=\mathrm{SE}$

smaller size categories make different choices or behave differently (e.g. potentially have a less defined home range, or more cryptic habits) compared to females and their larger male counterparts.

\section{Growth: sex and size}

Sexual size dimorphism in this species has been recorded throughout its range, with males clearly attaining much larger sizes than females within the same population (see Drew et al. 2010 for a review). This variation in size between sexes is not unusual in crustaceans and is potentially associated with the energetic costs of reproduction and/or sexual selection processes associated with mate choice (i.e. larger males outcompete smaller males for mates). Theory suggests that species subject to high male-male sexual competition are likely to have marked sexual dimorphism both in terms of body size and body structures used for weapons (Baeza \& Asorey 2012). 


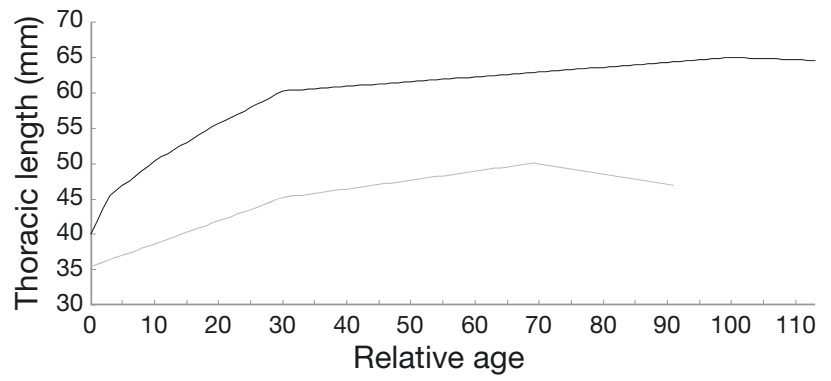

Fig. 8. Birgus latro. Relative age (yr) of individuals at thoracic length (TL) from starting values of $35.3 \mathrm{~mm}$ TL in females (grey line) and $49.9 \mathrm{~mm}$ TL in males (black line). Note: $x$-axis refers to the estimated number of yr to grow from the minimum size recaptured, not the total number of yr from metamorphosis to maximum size. All crabs recaptured were sexually mature and based on the growth curves provided by Fletcher et al. (1990a) all individuals were estimated to a minimum of $10 \mathrm{yr}$ old at tagging

Females are likely to devote energy to reproduction, which then prevents the use of this resource for growth, hence resulting in smaller individuals. No direct assessment has been made of energy investment in egg production in Birgus latro, however Helfman (1973, as cited in Fletcher at al. 1991) reported that a clutch of eggs in B. latro accounted for as much as $30 \%$ of the female body weight, presumably based on wet wt.

Fletcher et al. (1990a) reported relatively small increases in size for Birgus latro collected from the field and from crabs kept in captivity. Fletcher et al. (1990a) reported that males $>50 \mathrm{~mm}$ TL typically recorded only a 3 to $4 \% \mathrm{MI}$, whilst very large crabs (size not defined) were noted to increase ca. 1 to $2 \%$ of their initial TL per moult. Notably, Fletcher et al. (1990a) excluded crabs with zero or negative growth from their results. Exclusion of individuals with negative or zero growth in our study and adjusting the change in TL for each individual according to the number of full moult periods that occurred between recaptures resulted in the MI more closely approximating that reported by Fletcher et al. (1990a). The notable differences in the average MI between all moulted individuals and only those with positive MI in multiple size categories indicates that there may be substantial effects of excluding negative growth individuals on estimations of growth over time.

\section{Declining MI with increasing size}

Declining MI with size is a prevalent feature in crustaceans (Hartnoll 1983) and has been reported to occur in the robber crab (Fletcher et al. 1990a), the marine Dungeness crab Metacarcinus magister (Wainwright \& Armstrong 1993), the sand-dwelling hermit crab Diogenes nitidimanus (Asakura 1992) and a number of other aquatic crustaceans (Cockcroft \& Goosen 1995, Melville-Smith et al. 1995, Stewart \& Kennelly 2000, Luppi et al. 2004). In our study, it was clear that as individuals reached larger sizes, MI decreased. The reduction in growth recorded in Birgus latro with increasing size in our study may be associated with individuals reaching the physical limits of growth in a terrestrial environment. However, nothing definitive is known of the mechanism that may cause the decline in MI with increasing size in this or other crustacean species (Hartnoll 1983).

\section{Injury and negative growth}

In order to grow, terrestrial crabs usually take up water during the pre-moult period (proecdysis). This water is then used to expand the integument post moult but prior to hardening (Mason 1970, Hartnoll 1988). Hopkins (1982) proposed that the volume of water taken up during proecdysis may not vary between individual crabs with and without limb loss. Therefore crabs with limb loss may have insufficient ecdysial water to enable limb regeneration and carapace expansion simultaneously, and as such, may suffer zero or negative growth of the carapace (Hopkins 1982). This is more likely to affect individuals with multiple injuries, particularly if the injury hampered their capacity to obtain water, or prevented them from digging an ideal moult burrow.

Crabs in our study that had the most substantial loss of TL between tagging and recapture were those with a loss of cheliped and/or multiple limbs (Table 3). These crabs were most likely to have been disadvantaged in terms of movement, burrowing, climbing to escape predators, or ability to defend against aggressive conspecifics and hence, disadvantaged in their ability to access and maintain suitable shelter and foraging sites (Juanes \& Smith 1995). As with other crab species (e.g. blue crab Callinectes sapidus; Smith 1990) it was clearly evident that limb regeneration and cephalothorax repair in Birgus latro required at least 2 moults before the limb size matched that of the original limb or the cephalothorax was fully repaired and it is possible that MI could have been adversely affected until full regeneration had occurred.

Not surprisingly, limb or cheliped loss was much higher in males (Table 3). Males tended to fight aggressively to defend food and other resources throughout the year (M. M. Drew pers. obs.). The 
chelipeds or the first walking leg (a limb commonly used in aggressive interactions) were often lost, presumably as a result of these confrontations. The overall injury/deformity rate of $7.8 \%$ of the tagged population in this study is low compared to some, but not all, values reported in the review by Juanes \& Smith (1995) who reported injury rates in decapod crustaceans ranged from 1.75 to $66 \%$.

Although negative or zero growth was most evident in injured crabs it was not restricted to those with injuries and was observed in both males and females in all the size classes monitored. Several authors have noted that crustacean species may not grow during years of poor resources (Nicol et al. 1992, Cockcroft \& Goosen 1995) or if climatic conditions are not favourable (Marinovic \& Mangel 1999). Bliss \& Boyer (1964) noted that in the land crab Gecarcinus lateralis, a dry substratum during ecdysis could cause zero growth, stunted limb regeneration, and often resulted in a wrinkled appearance of the carapace. Loss of limbs or other injuries to the carapace in crustaceans have been shown to not only limit the moult increment (Hopkins 1982, Norman \& Jones 1991) but to also affect intermoult duration (Hopkins 1982) and have long term fitness effects by reducing mating and foraging success and increasing vulnerability to intra- and interspecies attack (Smith \& Hines 1991, Juanes \& Smith 1995).

It is probable that not all individuals monitored in this study moulted annually. As identified by Hartnoll (1982) the intermoult period in most crustaceans tends to increase with increasing size, with only a few exceptions. Thus crabs with zero or only minor changes in TL in our study may not have moulted that year, with the observed change in TL being a result of measurement error. As only paint was used as an external mark, which would last a maximum of about 7 to 8 mo (Drew et al. 2012; our Fig. 2c), there was no definitive way to assess if a crab had moulted between captures. A moult could not always be discerned from a photo, however, as longevity estimates in this study made no assumptions about moult frequency, growth estimates are likely to be accurate.

\section{Longevity of decapods}

A recent review by Vogt (2012) indicated that information on the longevity of decapods is extremely poor, with information available for $<2 \%$ of extant species. Vogt (2012) identified that of the decapod crustaceans that have been reliably aged, longevity ranges from between $40 \mathrm{~d}$ for a planktonic shrimp
(Lucifer faxoni) and $72 \mathrm{yr}$ in the European lobster Homarus gammarus. Vogt (2012) noted that the average rate for decapod crustaceans was between 1 and $10 \mathrm{yr}$. Of the terrestrial land crabs that have been reliably aged, the brachyuran Cardisoma guanhumi and the anomuran Coenobita clypeatus have been estimated to live to 20 and $30 \mathrm{yr}$, respectively (Burggren \& McMahon 1988, Linton \& Greenaway 1997, Vogt 2012).

Our study shows that negative or zero growth is a common occurrence in wild populations of Birgus latro on Christmas Island. Fletcher et al. (1990a) noted that $30 \%$ of the crabs that moulted in captivity recorded zero growth while $20 \%$ had negative growth. As these proportions are not substantially different to that recorded in the field on Christmas Island in this study, it is likely that the negative or zero growth recorded by Fletcher et al. (1990a) was a close reflection of what was occurring in wild populations. Using positive growth only and a simple noncontinuous growth curve, Fletcher et al. (1990a) estimated that $B$. latro may live between 30 and $50 \mathrm{yr}$. However, our study has identified that $B$. latro on Christmas Island do not exhibit growth every year, and may even experience negative growth. Our results indicate that $B$. latro on Christmas Island may live over $70 \mathrm{yr}$, with very large individuals likely to be over $100 \mathrm{yr}$. While these ages are considerably more than that recorded previously for other decapod crustaceans, B. latro grows to much larger sizes than the decapods reported above and it is likely that in order to reach its large size, $B$. latro would require much longer time frames to grow.

\section{CONCLUSIONS}

Birgus latro is an extremely slow-growing species that appears to commonly experience negative or zero growth in field situations. If $3 \mathrm{yr}$ of data from the present study are representative of growth in other populations, previous growth curves estimated with negative and zero growth individuals excluded are unlikely to accurately estimate the growth of $B$. latro over time. Continued data collection on tagged individuals on Christmas Island will provide a better understanding of growth variability in $B$. latro on this island. Future studies should attempt to confirm the assumption of an annual moult to ensure that the MI noted here is an accurate estimate of annual growth for individuals. The results of the present study highlight the importance of examining MI in natural situations in order to more accurately understand growth processes in a species' natural setting. 
Acknowledgements. We sincerely thank the following people for their invaluable efforts in the field, without which, much of this project could not have been achieved: K. Moorman, K. Schwartz, D. Hunter, D. Hardwick, J. Cope, J. Bignall, A. Derry, J. Woinarski, J. Kreiger, M. Kilian and the tireless team from Parks Australia North (Christmas Island): D. Maple, J. Bolton, T. Detto, C. Pink, P. Smith, R. Barr, R. Taylor, F. Napier, C. Boland, C. Humphries, M. Jenkins and many others. Also a sincere thank-you to R. Hartnoll for comments on an early version of the manuscript. This project was funded by the Max Planck Society.

\section{LITERATURE CITED}

Amesbury SS (1980) Biological studies on the coconut crab (Birgus latro) in the Mariana Islands. Marine Laboratory Technical Report No 66, University of Guam, Mangilao

- Asakura A (1992) Population ecology of the sand-dwelling hermit crab Diogenes nitidimanus Terao. 5. Ecological implications in the pattern of molting. J Crustac Biol 12: 537-545

- Baeza JA, Asorey CM (2012) Testing the role of male-male competition in the evolution of sexual dimorphism: a comparison between two species of porcelain crabs. Biol J Linn Soc 105:548-558

Bliss DE, Boyer JR (1964) Environmental regulation of growth in the decapod crustacean Gecarcinus lateralis. Gen Comp Endocrinol 4:15-41

Brooks SP, Gelman A (1998) General methods for monitoring convergence of iterative simulations. J Comput Graph Statist 7:434-455

Brown IW, Fielder DR (1991) The coconut crab: aspects of Birgus latro biology and ecology in the Republic of Vanuatu. ACIAR Monograph No. 8. Australian Centre for International Agricultural Research, Canberra

Buden DW (2012) The coconut crabs (Birgus latro, Anomura: Coenobitidae) of Soral Atoll, Yap, with remarks on the status of $B$. latro in the Federation States of Micronesia. Pac Sci 66:509-522

Burggren WW, McMahon BR (eds) (1988) Biology of the land crabs. Cambridge University Press, Melbourne

Chang YJ, Sun CL, Chen Y, Yeh SZ (2011) Modelling the growth of crustacean species. Rev Fish Biol Fish 22: 157-187

> Cockcroft AC, Goosen PC (1995) Shrinkage at moulting in the rock lobster Jasus lalandii and associated changes in reproductive parameters. S Afr J Mar Sci 16:195-203

Drew MM, Harzsch S, Stensmyr M, Erland S, Hansson BS (2010) A review of the biology and ecology of the robber crab, Birgus latro (Linnaeus, 1767) (Anomura: Coenobitidae). Zool Anz 249:45-67

> Drew MM, Hartnoll RG, Hansson BS (2012) An improved mark-recapture method using passive integrated transponder (PIT) tags in Birgus latro (Linnaeus, 1767). Crustaceana 85:89-102

Eldredge LG (1996) Birgus latro, 2008 IUCN Red List of threatened species (accessed 23 Feb 2009). www.iucnredlist.org

Environment Unit (2006) Third National report to the conference of parties of the convention on biodiversity. Environment Unit Vanuatu, Port Villa

Fletcher WJ, Amos M (1994) Stock assessment of coconut crabs. ACIAR Monograph Series No 29. Australian Centre for International Agricultural Research, Canberra
Fletcher WJ, Fielder DR, Brown IW (1989) Comparison of freeze and heat-branding techniques to mark the coconut crab Birgus latro (Crustacea, Anomura). J Exp Mar Biol Ecol 127:245-251

- Fletcher WJ, Brown IW, Fielder DR (1990a) Growth of the coconut crab Birgus latro in Vanuatu. J Exp Mar Biol Ecol 141:63-78

Fletcher WJ, Brown IW, Fielder DR (1990b) Movement of coconut crabs, Birgus latro, in a rainforest habitat in Vanuatu. Pac Sci 44:407-416

Fletcher WJ, Brown IW, Fielder DR (1991) Chapter 3: Moulting and growth charateristics. In: Brown IW, Fielder DR (eds) The coconut crab: aspects of Birgus latro biology and ecology in the Republic of Vanuatu, Vol 8. Australian Centre for International Agricultrual Research, Canberra, p 35-60

Gelman A, Hill J (2007) Data analysis using regression and multilevel/hierarchical models. Cambridge University Press, New York, NY

Gibson-Hill CA (1947) Christmas Island-terrestrial crabs: field notes on the terrestrial crabs. Bull Raffles Mus 18: 43-52

Hartnoll RG (1982) Growth. In: Abele LG (ed) Biology of the Crustacea, Vol. 1. Academic Press, New York, NY, p 111-196

Hartnoll RG (1983) Strategies of crustacean growth. In: Lowry JK (ed) Biology and evolution of Crustacea. Australian Museum Memoir 18, Trustees of the Australian Museum, Australian Museum, Sydney, p 121-131

Hartnoll RG (1988) Chapter 6: Growth and molting. In: Burggren WW, McMahon BR (eds) Biology of the land crabs. Cambridge University Press, Melbourne, p 186-210

Hartnoll RG (2001) Growth in Crustacea - twenty years on. Hydrobiologia 449:111-122

> Hartnoll RG (2006) Reproductive investment in Brachyura. A review. Hydrobiologia 557:31-40

Held EE (1963) Moulting behaviour of Birgus latro. Nature 200:799-800

Helfman GS (1973) The ecology and behaviour of the coconut crab Birgus latro (Linneaus). MSc thesis, University of Haiwaii, Honolulu

> Helfman GS (1977) Agonistic behaviour of the coconut crab, Birgus latro (Linneaus). Zeitschr Tierpsychol 43:425-438

Hopkins PM (1982) Growth and regeneration patterns in the fiddler crab, Uca pugilator. Biol Bull 163:301-319

Juanes F, Smith LD (1995) The ecological consequences of limb damage and loss in decapod crustaceans: a review and prospectus. J Exp Mar Biol Ecol 193:197-223

Kerman J (2011) Neutral noninformative and informative conjugate beta and gamma prior distributions. Electron $\mathrm{J}$ Stat 5:1450-1470

Kéry M (2010) Introduction to WinBugs for ecologists: a Bayesian approach to regression, ANOVA, mixed models and related analyses, 1 st edn. Academic Press, London

> Kilada R, Sainte-Marie B, Rochette R, Davis N, Vanier C, Campana $S$ (2012) Direct determination of age in shrimps, crabs, and lobsters. Can J Fish Aquat Sci 69: 1728-1733

Lavery S, Moritz C, Fielder DR (1996) Indo-Pacific population structure and evolutionary history of the coconut crab Birgus latro. Mol Ecol 5:557-570

Linton S, Greenaway P (1997) Urate deposits in the gecarcinid land crab Gecarcoidea natalis are synthesised de novo from excess dietary nitrogen. J Exp Biol 200: 2347-2354 
Lunn D, Spiegelhalter D, Thomas A, Best N (2009) The BUGS project: evolution, critique and future directions. Stat Med 28:3049-3067

Luppi TA, Spivak ED, Bas CC, Anger K (2004) Molt and growth of an estuarine crab, Chasmagnathus granulatus (Brachyura: Varunidae), in Mar Chiquita coastal lagoon, Argentina. J Appl Ichthyology 20:333-344

Marinovic B, Mangel M (1999) Krill can shrink as an ecological adaptation to temporarily unfavourable environments. Ecol Lett 2:338-343

Mason CA (1970) Function of the pericardial sacs during the molt cycle in the land crab Gecarcinus lateralis. J Exp Zool 174:381-390

Melville-Smith R, Goosen PC, Stewart TJ (1995) The spiny lobster Jasus lalandii (H. Milne Edwards, 1837) off the South African coast: inter-annual variations in male growth and female fecundity. Crustaceana 68:174-183

- Nicol S, Stolp M, Cochran T, Geijsel P, Marshall J (1992) Growth and shrinkage of Antarctic krill Euphausia superba from the Indian Ocean sector of the Southern Ocean during summer. Mar Ecol Prog Ser 89:175-181

> Norman CP, Jones MB (1991) Limb loss and its effect on handedness and growth in the velvet swimming crab Necora puber (Brachyura: Portunidae). J Nat Hist 25: 639-645

R Development Core Team (2007) R: A language and environment for statistical computing. R Foundation for Statistical Computing, Vienna

Reese ES, Kinzie RA (1968) The larval development of the coconut crab or robber crab Birgus latro (Linneaus) in the laboratory (Anomura, Paguridea). Crustaceana(Suppl 2): $117-144$

Robertson M (1991) Husbandry and moulting behaviour of the robber or coconut crab Birgus latro: at London Zoo. Int Zoo Yearb 30:60-67

Royle JA, Dorazio RM (2008) Hierarchical modeling and inference in ecology. First Academic Press, London

Sato T, Yoseda K (2008) Reproductive season and female

Editorial responsibility: Bernard Sainte-Marie,

Mont-Joli, Quebec, Canada maturity size of coconut crab Birgus latro on Hatoma Island, southern Japan. Fish Sci 74:1277-1282

Sato T, Yoseda K (2010) Influence of size- and sex-biased harvesting on reproduction of the coconut crab Birgus latro. Mar Ecol Prog Ser 402:171-178

Sato T, Yoseda K, Abe O, Shibuno T (2008) Male maturity, number of sperm, and spermatophore size relationships in the coconut crab Birgus latro on Hatoma Island, southern Japan. J Crustac Biol 28:663-668

Schiller CB (1992) Assessment of the status of the coconut crab Birgus latro on Niue Island with recommendations regarding an appropriate resource management strategy. Prepared for The Food and Agricultural Organisation of the United Nations, by the University of Queensland, Brisbane

Schiller C (1993) Early development and larval ecology of the coconut crab Birgus latro (Linneaus). PhD thesis, University of Queensland, Brisbane

Sheehy MRJ, Bannister RCA, Wickins JF, Shelton PMJ (1999) New perspectives on the growth and longevity of the European lobster (Homarus gammarus). Can J Fish Aquat Sci 56:1904-1915

Smith DL (1990) Patterns of limb loss in the blue crab, Callinectes Sapidus Rathbun, and the effects of autotomy on growth. Bull Mar Sci 46:23-36

Smith LD, Hines AH (1991) The effect of cheliped loss on blue crab Callinectes sapidus Rathbun foraging rate on soft-shell clams Mya arenaria L. J Exp Mar Biol Ecol 151: $245-256$

Stewart J, Kennelly SJ (2000) Growth of the scyllarid lobsters Ibacus peronii and I. chacei. Mar Biol 136:921-930

Sturtz S, Ligges U, Gelman A (2005) R2WinBUGS: a package for running WinBUGS from R. J Stat Softw 12:1-16

Vogt G (2012) Ageing and longevity in the Decapoda (Crustacea): a review. Zool Anz 251:1-25

Wainwright TC, Armstrong DA (1993) Growth patterns in the dungeness crab (Cancer magister Dana): synthesis of data and comparison of models. J Crustac Biol 13:36-50

Submitted: November 13, 2012; Accepted: July 9, 2013

Proofs received from author(s): September 12, 2013 